\title{
Physical activity in periods of social distancing due to COVID-19: a cross-sectional survey
}

\author{
Atividade física em períodos de distanciamento social \\ devidos à COVID-19: um estudo transversal
}

Edson Zangiacomi Martinez (https://orcid.org/0000-0002-0949-3222) ${ }^{1}$
Fabrícia Mabelle Silva (https://orcid.org/0000-0001-7197-6236) ${ }^{1}$
Thais Zanin Morigi (https://orcid.org/0000-0003-0159-9644) ${ }^{1}$
Miriane Lucindo Zucoloto (https://orcid.org/0000-0002-4745-227X) ${ }^{1}$
Thaise Lucena Silva (https://orcid.org/0000-0001-9797-7288) ${ }^{2}$
Anderson Gregorio Joaquim (https://orcid.org/0000-0002-6289-675X) ${ }^{1}$
Gabriela Dall'Agnol (https://orcid.org/0000-0001-6919-3873) ${ }^{1}$
Guilherme Galdino (https://orcid.org/0000-0002-7637-2340) ${ }^{1}$
Maisa Oliveira Zangiacomi Martinez (https://orcid.org/0000-0001-9110-2827) ${ }^{3}$
Wanderson Roberto da Silva (https://orcid.org/0000-0001-8897-8772) ${ }^{4}$

${ }^{1}$ Faculdade de Medicina de Ribeirão Preto, Universidade de São Paulo. Av.

Bandeirantes 3900, Monte

Alegre. 14049-900 Ribeirão

Preto SP Brazil.

edson@fmrp.usp.br

${ }^{2}$ Instituto Municipal de

Ensino Superior. Catanduva

SP Brasil.

${ }^{3}$ Instituto de Ciências da Saúde, Universidade Federal do Triângulo Mineiro.

Uberaba MG Brasil.

${ }^{4}$ Faculdade de Ciências

Farmacêuticas, Universidade Estadual Paulista Júlio de

Mesquita Filho. Araraquara

SP Brasil.

\begin{abstract}
Physical inactivity and sedentary behavior are associated with poor physical and mental health. The article aims to assess the changes in the habits of the Brazilian participants engaged in physical activities in relation to their practices, due the measures of social distancing during the COVID-19 epidemic in 2020. The secondary objective was to describe their levels of anxiety and depression. The questionnaire used in this online survey included demographic information, questions about self-perceptions of the impact of the COVID-19 in the life routines and the 14-item Hospital Anxiety Depression Scale. A total of 1,613 adults completed the questionnaire between May 11 and 15, 2020. Of those, 79.4\% reported that the measures to contain the epidemic had any impact on their physical activities, and many had to interrupt or decrease the frequency of their practices. Participants who felt a higher impact of quarantine on their physical activities tend to have higher prevalence of anxiety and depression symptoms. Individuals who practiced physical activities reported that social distance had a high influence on their practices. Furthermore, changes in these habits are associated with high levels of poor mental health.
\end{abstract}

Key words COVID-19, SARS-CoV-2, Physical activity, Social distancing, Mental health
Resumo Inatividade fisica e sedentarismo são associados com baixa saúde física e mental. O objetivo deste artigo é avaliar as mudanças nos hábitos dos participantes brasileiros praticantes de atividades físicas em relação às suas práticas, devido às medidas de distanciamento social durante a epidemia COVID-19 em 2020. O objetivo secundário foi descrever seus niveis de ansiedade e depressão. O questionário utilizado nesta pesquisa on-line incluiu informações demográficas, questões sobre a autopercepção do impacto do COVID-19 nas rotinas da vida e a Escala de Depressão de Ansiedade Hospitalar de 14 itens. Um total de 1.613 adultos completou o questionário entre 11 e 15 de maio de 2020. Destes, 79,4\% relataram que as medidas para conter a epidemia tiveram algum impacto em suas atividades fisicas e muitos tiveram que interromper ou diminuir a frequência de suas práticas. Os participantes que sentiram um maior impacto da quarentena em suas atividades físicas tendem a ter maior prevalência de sintomas de ansiedade e depressão. Os indivíduos que praticavam atividades físicas relataram que o distanciamento social teve alta influência em suas práticas. Além disso, as mudanças destes hábitos são associadas com altos níveis de precária saúde mental.

Palavras-chave COVID-19, SARS-CoV-2, Atividade física, Distanciamento social, Saúde mental 


\section{Introduction}

Coronavirus disease (COVID-19) is caused by a RNA virus named the severe acute respiratory syndrome coronavirus 2 (SARS-CoV-2), introduced to human populations in November or December $2019^{1,2}$. The first cases of the disease appeared in Wuhan, the capital city of Chinese Hubei Province, and the COVID-19 quickly spread outside China reaching practically every country in the world ${ }^{1}$. On January 30, 2020, the World Health Organization (WHO) considered COVID-19 to be a global health emergency ${ }^{3}$. In Brazil, COVID-19 was declared as a public health emergency on February 3, 2020, and on February 6, the Brazilian Ministry of Health approved the law 13979 with measures that included isolation and quarantine ${ }^{4,5}$. The first case of the disease in Brazil was registered on February 26, 2020 in São Paulo ${ }^{4,6}$, and as of May 14, 202,918 reported cases and 13,993 deaths had been registered all over the country (official data from the Brazilian Ministry of Health $)^{7}$. The social distancing measures and quarantine requirements resulted in the temporary closing of many crowded environments including fitness centers and public gyms. Although essential to decrease the spread of the disease, these measures reduced opportunities to remain physically active, probably influencing the increase in sedentary lifestyle and physical inactivity of the population.

Physical activity is recognized as an essential component of healthy living and quality of life, helping in the prevention and treatment of chronic diseases and in the overall maintenance of physical and mental health ${ }^{8-10}$. Some authors have been highlighting a J-shaped relation between physical activity and respiratory track viral infection, where moderate intensity activity can boost the immune system and the risk of respiratory track viral infections are thus substantially reduced. On the other hand, high intensity activity with long durations can weak the immune system for several hours following the exercise, increasing the risk of inspiratory track infections in this period ${ }^{11,12}$. This leads to the conclusion that moderate-intensity exercise should be recommended for healthy asymptomatic people during the COVID-19 pandemic, but precautions are needed concerning high-intensity exercises ${ }^{13}$. Considering that public gyms and crowded environments should be avoided in order to reduce the risk of infection, moderately intense physical activity can be encouraged in private environments with good ventilation and use of personal equipment ${ }^{11,14}$. In this way, numerous fitness centers have been posting free online workout routines to help people remain active at home ${ }^{15}$.

Although we find in the literature different reports with recommendations for homebased physical exercises during the pandemic $^{10,13-20}$, there are still few studies on the effects of COVID-19 on the daily lives of people who practice physical activities. A Brazilian study on the behavioral and psychosocial aspects of the social isolation during the COVID-19 pandemic showed that people with higher stress, depression and state anxiety levels were performing less physical activities when compared with people with better mental health ${ }^{21}$. These results highlight the importance of new and specific studies on the possible impacts of the COVID-19 pandemic on the physical activity habits of the population.

Considering the physically active lifestyle as an important coping strategy for dealing with stressful events and for protecting the physical and mental health during the COVID-19 pandemic $^{22}$, the objective of this study is to assess the changes in the habits of the Brazilian population engaged in physical activities in relation to their practices, due the measures of social distancing. As a secondary objective, we sought to describe the levels of anxiety and depression of this population, during the period of social distancing.

\section{Methods}

\section{Sample and procedures}

The present study involved a cross-sectional survey based on a web-based self-administered questionnaire. To ensure the quality of data reporting, it was used the guidelines from the CHERRIES protocol ("Checklist for Reporting Results of Internet E-Surveys") ${ }^{23}$. The questionnaire was designed and implemented on the REDCap platform ("Research Electronic Data Capture") $)^{24}$, and the link of the questionnaire was disseminated electronically via WhatsApp and social networking sites as Facebook. The welcome page of the questionnaire assessed though the link included in addition to the invitation to participate, information about the inclusion criteria, objectives and procedures of the study and the informed consent form. After this step, having agreed to these terms and declared to be 18 years of age or older, participants had access 


\section{Sample characterization and study variables}

The electronic questionnaire included demographic information (age, gender, occupation, size of household, marital status, level of education), smoking status, frequency of physical activity before the period of social distancing, and questions about self-perceptions of the impact of the COVID-19 in their physical activities and life routines. It was also asked to the participants if they consider themselves professional athletes and if they have a gym room in their homes. The educational level was classified into five groups: insufficient (including illiterates, people who have never attended school and people who did not complete the fundamental I level), fundamental I, fundamental II, medium school, and higher education. In the Brazilian educational system, "fundamental I" is equivalent to years 1 to 5 of the elementary education while "fundamental II" is equivalent to years 6 to 9, "medium school" corresponds to the high school and "higher education" corresponds to the college, undergraduate schools or university level courses. Self-perception of health is an indicator of quality of life and subjective well-being ${ }^{25}$, and in the present study it was measured using the single item How do you perceive your health?, whose possible responses were good, regular and poor ${ }^{26}$. The participants were asked to respond to the following questions: At the moment, in your city, is there an official recommendation to stay home because of the COVID-19 epidemic?, How often do you seek information about the COVID-19? and How much an epidemic as the current by COVID-19 makes you anxious?. The questionnaire also included the questions: How do you assess the impact of measures to contain the COVID-19 epidemic on your physical activities? and In general, how do you assess the impact of measures to contain the COVID-19 epidemic on your daily life?. The possible responses to both questions were very great, great, low, and nothing has changed.
Participants were asked to report on the physical activities they practiced until the beginning of the social distancing measures. The electronic questionnaire included the following activities: strength, resistance and power training (including functional training, lift weight, localized exercises, body weight exercises, machines exercises, and cross-fit), aerobic training (high intensity interval training [HIIT] or moderate intensity continuous training [MICT] in treadmills, cycle ergometer, indoor cycling class, stair simulator, step, and others), stretching, dance (ballet, jazz, ballroom dance, Zumba, poly dance, and others), martial arts, capoeira, Pilates, circus arts, slackline, acrobatic gymnastics, Yoga, Tai-Chi-Chuan, Lian Gong, cross-fit, meditation, hydrogymnastics, climbing, outdoor activities (including hiking, trekking, cycling, and others), indoor or field sports (including soccer, volleyball, basketball, tennis, rugby, and others), water sports (swimming, water polo, surfing, and others), and athletics (all modalities). Although meditation may not be properly classified as a physical activity, this practice was included in this study since it can provide significant improvements in respiratory function and be used as an emotional coping strategy during the COVID-19 pandemic ${ }^{27}$.

\section{Psychometric measure}

The 14-item Hospital Anxiety Depression Scale (HADS $)^{28}$ was used to assess the mental well-being among the participants. This brief questionnaire was introduced by Zigmond and Snaith ${ }^{29}$ and cross-culturally adapted in Portuguese language by Botega et al. ${ }^{30}$. This instrument consists of 14 items with a 4-point Likert type response scale (ranging from 0 to 3 points) grouped into anxiety and depression subscales (each ranging from 0 to 21 points). A literature review of papers addressing the performance of HADS in the detection of anxiety disorders and depression showed that an optimal balance between sensitivity and specificity was achieved when a cut-off value is defined by a score of 8 or above on both subscales ${ }^{31}$. According to Bernik and Lotufo-Neto ${ }^{32}$, the HADS does not address very severe symptoms, typical of psychiatric patients, being useful in the evaluation of non-clinical populations, including population samples.

\section{Statistical analysis}

The collected data was organized in frequency tables and percentages. Associations between 
anxiety and depression and variables of interest were assessed using log-binomial regression models $s^{33}$. These models allowed to estimate gender- and age-adjusted prevalence ratios (PR) as association measures, with $95 \%$ confidence intervals $(95 \% \mathrm{CI})$. Confidence intervals not including 1 imply evidence of association between the correspondent variables (similar to $\mathrm{p}<0.05$ ). All statistical analyses were performed using $\mathrm{R}$ version 3.6.2.

\section{Results}

At the time of data collection, 2,230 respondents had accessed the questionnaire. Of those, 1,613 $(72.3 \%)$ agreed to participate, met the inclusion criteria and started to answer the questionnaire. Only participants who answered all questions of the questionnaire were included in the present analysis. Thus, the final sample was composed of $1,017(63.1 \%)$ women with mean age of 35.4 years (standard deviation [SD] 12.0) and 596 (36.9\%) men with mean age of 36.2 years (SD 10.9). Table 1 provides a description of the participants. Only 48 participants (3.0\%) consider themselves professional athletes and a large majority of respondents $(98.6 \%)$ declared that at the time of the survey there were official recommendation in their cities to stay home because of the COVID-19 epidemic.

Table 2 shows that $79.4 \%$ of the participants reported that the measures to contain the COVID-19 epidemic had great or very great impact on their physical activities. In a general manner, $90.6 \%$ of the participants reported that these measures had great or very great impact on their daily life, with $35.7 \%$ of those who are students having their school or academic activities completely interrupted. Only $16.4 \%$ of those who have any professional activity did not report changes in their routines. A large majority of participants (93.4\%) agree that the COVID-19 is a major public health concern and $79.6 \%$ agree that the social distancing was the right measure to contain the spread of the disease.

Table 3 shows the percentages of participants who practiced each activity included in the questionnaire until the beginning of the social distancing measures, the effects on practice time during the COVID-19 epidemic, and the number of people who started to practice the activities during the period of social distancing. The results in Table 3 suggest that there is an effect of gender on the choice of activities practiced.
Activities, such as dance, Pilates, yoga, meditation are most practiced by woman, while activities such as martial arts, indoor or field sports, water sports and athletics are most practiced by man. In a general manner, strength training and aerobic training are the physical activities most practiced by the respondents until the beginning of the social distancing measures. Hydrogymnastics, climbing, outdoor or field sports and water sports had a more expressive effect due to social distancing, since more than $90 \%$ of the practitioners have stopped practicing them. We can also observe that activities that are not dependent on devices, such as HIIT, yoga, Tai-Chi-Chuan and Lian Gong, and meditation, appeared to have a relatively low impact due the social distancing measures. As a special case, the social distancing measures due to COVID-19 had a little effect on the practice of meditation, with only $11.9 \%$ having stopped practicing and 129 respondents reported having started their practice during the period of these measures. Climbing was the activity least cited by respondents $(0.3 \%)$, but at the same time the one that seemed to suffer the greatest impact from social distancing measures (all of the practitioners have stopped practicing it). Surprisingly, 10 people reported starting their practice during the social distancing measures.

When asked about their resources used to maintaining the physical activities during the period of social distancing, 36\% reported using the knowledge they already had, $22.6 \%$ had online classes or instructions, $19.8 \%$ watched videos from the internet, $15.7 \%$ of the participants reported that they watched live-stream videos, $10.9 \%$ received remote monitoring from a personal trainer, $8.9 \%$ received remote monitoring from the gym they attended, $3.2 \%$ received instructions from others in their household, $2 \%$ had outdoor classes, $1.4 \%$ used books, magazines, e-books and booklets, and $0.7 \%$ watched videos in TV streaming services.

The mean score for anxiety subscale was 10.1 (SD 2.7) and the mean score for depression subscale was 7.8 (SD 2.5). A large majority of respondents $(82.6 \%)$ had scores higher or equal to eight for the scale of anxiety, and $48.8 \%$ had scores above this cut-off for the scale of depression.

Table 4 describes the association between HADS scores and selected variables. HADS anxiety and/or depression scores greater than or equal to eight indicated psychological morbidity. In this way, almost half of the participants (48.8\%) were classified as having depression symptoms and most were classified as having anxiety symptoms 
Table 1. Characteristics of the study participants $(n=1,613)$.

\begin{tabular}{|c|c|c|c|c|}
\hline & & $\begin{array}{l}\text { Male } \\
\text { n (\%) }\end{array}$ & $\begin{array}{c}\text { Female } \\
\text { n (\%) }\end{array}$ & $\begin{array}{l}\text { Total } \\
\text { n (\%) }\end{array}$ \\
\hline \multirow[t]{9}{*}{ Age (years) } & $18-20$ & $22(3.7)$ & $75(7.4)$ & $97(6.0)$ \\
\hline & $21-25$ & $85(14.3)$ & $172(16.9)$ & $257(15.9)$ \\
\hline & $26-30$ & $101(16.9)$ & $173(17.0)$ & $274(17.0)$ \\
\hline & $30-35$ & $108(18.1)$ & $145(14.3)$ & $253(15.7)$ \\
\hline & $36-40$ & $84(14.1)$ & $127(12.5)$ & $211(13.1)$ \\
\hline & $41-45$ & $84(14.1)$ & $126(12.4)$ & $210(13.0)$ \\
\hline & $46-50$ & $39(6.5)$ & $70(6.9)$ & $109(6.8)$ \\
\hline & $51-60$ & $57(9.6)$ & $93(9.1)$ & $150(9.3)$ \\
\hline & $>60$ & $16(2.7)$ & $36(3.5)$ & $52(3.2)$ \\
\hline \multirow[t]{5}{*}{ Education level } & Insufficient & $1(0.2)$ & $1(0.1)$ & $2(0.1)$ \\
\hline & Fundamental I & $4(0.7)$ & $4(0.4)$ & $8(0.5)$ \\
\hline & Fundamental II & $6(1.0)$ & $15(1.5)$ & $21(1.3)$ \\
\hline & Medium school & $136(22.8)$ & $248(24.4)$ & $384(23.8)$ \\
\hline & Higher education & 449 (75.3) & 749 (73.6) & $1,198(74.3)$ \\
\hline \multirow[t]{6}{*}{ Size of household } & Live alone & $87(14.6)$ & $125(12.3)$ & $212(13.1)$ \\
\hline & 2 people & $161(27.0)$ & $278(27.3)$ & $439(27.2)$ \\
\hline & 3 people & $175(29.4)$ & $277(27.2)$ & $452(28.0)$ \\
\hline & 4 people & $124(20.8)$ & $256(25.2)$ & $380(23.6)$ \\
\hline & 5 people & $36(6.0)$ & $64(6.3)$ & $100(6.2)$ \\
\hline & More than 5 people & $13(2.2)$ & $17(1.7)$ & $30(1.9)$ \\
\hline \multirow[t]{5}{*}{ Marital status } & Single & $272(45.6)$ & $492(48.4)$ & $764(47.4)$ \\
\hline & Married & $293(49.2)$ & $424(41.7)$ & $717(44.5)$ \\
\hline & Separated & $21(3.5)$ & $70(6.9)$ & $91(5.6)$ \\
\hline & Widowed & $3(0.5)$ & $16(1.6)$ & $19(1.2)$ \\
\hline & Other & $7(1.2)$ & $15(1.5)$ & $22(1.4)$ \\
\hline \multirow[t]{11}{*}{ Occupation } & Wage worker & $247(41.4)$ & $340(33.4)$ & $587(36.4)$ \\
\hline & Self-employed & $109(18.3)$ & $175(17.2)$ & $284(17.6)$ \\
\hline & Student & $73(12.2)$ & $207(20.4)$ & $280(17.4)$ \\
\hline & Businessman & $89(14.9)$ & $75(7.4)$ & $164(10.2)$ \\
\hline & Unemployed & $16(2.7)$ & $54(5.3)$ & $70(4.3)$ \\
\hline & Retired & $15(2.5)$ & $42(4.1)$ & $57(3.5)$ \\
\hline & Researcher & $10(1.7)$ & $46(4.5)$ & $56(3.5)$ \\
\hline & Informal worker & $19(3.2)$ & $32(3.1)$ & $51(3.2)$ \\
\hline & Housewife & $1(0.2)$ & $23(2.3)$ & $24(1.5)$ \\
\hline & Trainee & $11(1.8)$ & $12(1.2)$ & $23(1.4)$ \\
\hline & Freelancer & $6(1.0)$ & $11(1.1)$ & $17(1.1)$ \\
\hline
\end{tabular}

it continues

(82.6\%). Age- and gender-adjusted prevalence ratios show that anxiety is more frequent among females, young adults and people with higher education. However, these variables are not associated with depression symptoms. The results also indicated that participants who felt a higher impact of the social distancing measures on physical activities tend to have higher prevalence of anxiety and depression symptoms. Moreover, Table 4 shows that participants reporting a poor or regular self-perception of health have higher prevalence of these conditions. We also can see that there is a higher prevalence of depression symptoms among the people who disagree that 


\begin{tabular}{|c|c|c|c|c|c|}
\hline \multirow[t]{24}{*}{ 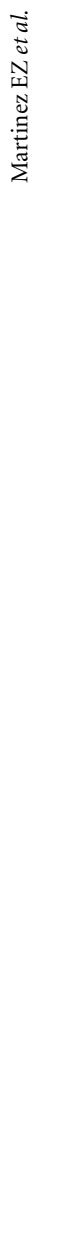 } & Table 1. Characteristics of & e study participants ( $n=$ & 613). & & \\
\hline & & & $\begin{array}{l}\text { Male } \\
\text { n (\%) }\end{array}$ & $\begin{array}{c}\text { Female } \\
\text { n (\%) }\end{array}$ & $\begin{array}{l}\text { Total } \\
\text { n }(\%)\end{array}$ \\
\hline & Smoking status & Never smoker & $461(77.3)$ & $852(83.8)$ & $1,313(81.4)$ \\
\hline & & Smoker & $52(8.7)$ & $58(5.7)$ & $110(6.8)$ \\
\hline & & Ex-smoker & $83(13.9)$ & $107(10.5)$ & $190(11.8)$ \\
\hline & Professional athlete & Yes & $24(4.0)$ & $24(2.4)$ & $48(3.0)$ \\
\hline & & No & $572(96.0)$ & $993(97.6)$ & $1,565(97.0)$ \\
\hline & Has a gym room at home & Yes & $54(9.1)$ & $77(7.6)$ & $131(8.1)$ \\
\hline & & No & $542(90.9)$ & $940(92.4)$ & $1,482(91.9)$ \\
\hline & Self-perception of health & Good & $504(84.6)$ & $803(79.0)$ & $1,307(81.0)$ \\
\hline & & Regular & $90(15.1)$ & $210(20.6)$ & $300(18.6)$ \\
\hline & & Poor & $2(0.3)$ & $4(0.4)$ & $6(0.4)$ \\
\hline & Recommendations for & Yes & $589(98.8)$ & $1,001(98.4)$ & $1,590(98.6)$ \\
\hline & staying at home & No & $7(1.2)$ & $12(1.2)$ & $19(1.2)$ \\
\hline & & Do not know & 0 & $4(0.4)$ & $4(0.2)$ \\
\hline & Frequency of & Less than 1 day a week & $14(2.3)$ & $22(2.2)$ & $36(2.2)$ \\
\hline & physical activity & 1 day a week & $9(1.5)$ & $31(3.0)$ & $40(2.5)$ \\
\hline & before the period of & 2 days a week & $35(5.9)$ & $125(12.3)$ & $160(9.9)$ \\
\hline & social distancing due to & 3 days a week & $99(16.6)$ & $253(24.9)$ & $352(21.8)$ \\
\hline & COVID-19 & 4 days a week & $103(17.3)$ & $178(17.5)$ & $281(17.4)$ \\
\hline & & 5 days a week & $172(28.9)$ & $238(23.4)$ & $410(25.4)$ \\
\hline & & 6 days a week & $107(18.0)$ & $114(11.2)$ & $221(13.7)$ \\
\hline & & 7 days a week & $57(9.6)$ & $54(5.3)$ & $111(6.9)$ \\
\hline & & Do not know & 0 & $2(0.2)$ & $2(0.1)$ \\
\hline
\end{tabular}

the COVID-19 is a major public health concern and social distancing was the right public measure.

\section{Discussion}

Physical activity is associated with reduced depressive and anxiety symptoms in multiple populations $^{34,35}$, and the results of this study highlight a very large number of people with symptoms of anxiety and depression according to the HADS, which is compatible with the literature. Using the HADS, a Chinese study including hospitalized patients with COVID-19 estimated that $34.7 \%$ and $28.5 \%$ of the participants presented symptoms of anxiety and depression, respectively ${ }^{36}$. In this study, the mean score of anxiety and depression subscales for all patients was 6.4 (SD 4.3) and 5.4 (SD 4.3), respectively. In a study including the Mexican general population, the prevalence for anxiety and depression was 50\% and $27.6 \%$, respectively, during the initial phase of the COVID-19 pandemic $^{37}$. Other population-based study carried out before the COVID-19 pandemic show anxiety mean values ranging from 3.6 in Hong Kong ${ }^{38}$ to 6.4 in the United Kingdom ${ }^{39}$, while the depression means range between 3.3 Hong Kong ${ }^{38}$ and 6.6 in Korea ${ }^{40,41}$.

Our results suggest that participants who are against the social distancing measures and do not agree that COVID-19 is a major public health concern tend to have higher prevalence of depression symptoms, while the prevalence of anxiety symptoms is lower among the respondents who reported a low impact of the social distancing on daily life. These findings also help to highlight a deep impact of the pandemic by COVID-19 on mental health of the population, and show that there is a global demand for strategies to improve the coping and adaptation process in a situation of social isolation. A number of authors have been argued that physical activities are a key strategy in these periods of prolonged stay at home ${ }^{13-19}$, since their benefits are not only related to mental health, but their practice can also improves the immune response to infections, impacting the severity of symptoms and the clinical outcome for 
Table 2. Impacts of the COVID-19 epidemic and the measures to contain the disease on the physical activities and other daily life activities $(n=1,613)$.

\begin{tabular}{|c|c|c|c|c|}
\hline & & $\begin{array}{l}\text { Male } \\
\text { n (\%) }\end{array}$ & $\begin{array}{c}\text { Female } \\
\text { n }(\%)\end{array}$ & $\begin{array}{l}\text { Total } \\
\text { n }(\%)\end{array}$ \\
\hline \multirow{4}{*}{$\begin{array}{l}\text { How do you assess the impact } \\
\text { of measures to contain the } \\
\text { COVID-19 epidemic on your } \\
\text { physical activities? }\end{array}$} & Very large & $265(44.5)$ & $441(43.4)$ & $706(43.8)$ \\
\hline & Large & $218(36.6)$ & $357(35.1)$ & $575(35.6)$ \\
\hline & Low & $93(15.6)$ & $185(18.2)$ & $278(17.2)$ \\
\hline & Nothing has changed & $20(3.4)$ & $34(3.3)$ & $54(3.3)$ \\
\hline \multirow{4}{*}{$\begin{array}{l}\text { In general, how do you assess } \\
\text { the impact of measures } \\
\text { to contain the COVID-19 } \\
\text { epidemic on your daily life? }\end{array}$} & Very large & $310(52.0)$ & $537(52.8)$ & $847(52.5)$ \\
\hline & Large & $234(39.3)$ & $380(37.4)$ & $614(38.1)$ \\
\hline & Low & $45(7.6)$ & $94(9.2)$ & $139(8.6)$ \\
\hline & Nothing has changed & $7(1.2)$ & $6(0.6)$ & $13(0.8)$ \\
\hline \multirow{4}{*}{$\begin{array}{l}\text { How often do you seek } \\
\text { information about the } \\
\text { COVID-19? }\end{array}$} & All the time & $98(16.4)$ & $115(11.3)$ & $213(13.2)$ \\
\hline & Many times a day & $187(31.4)$ & $255(25.1)$ & $442(27.4)$ \\
\hline & A few times a day & $243(40.8)$ & $517(50.9)$ & $760(47.1)$ \\
\hline & Almost never & $68(11.4)$ & $129(12.7)$ & $197(12.2)$ \\
\hline \multirow{4}{*}{$\begin{array}{l}\text { How much an epidemic as the } \\
\text { current by COVID- } 19 \text { makes } \\
\text { you anxious? }\end{array}$} & Very anxious & $169(28.4)$ & $410(40.4)$ & $579(35.9)$ \\
\hline & Moderately anxious & $228(38.3)$ & $413(40.6)$ & $641(39.8)$ \\
\hline & Low anxious & $148(24.9)$ & $157(15.5)$ & 305 (18.9) \\
\hline & Nothing anxious & $50(8.4)$ & $36(3.5)$ & $86(5.3)$ \\
\hline \multirow{4}{*}{$\begin{array}{l}\text { Were your school/academic } \\
\text { activities interrupted during } \\
\text { the epidemic? } \\
\text { ^ Only students responded on } \\
\text { this question }\end{array}$} & Completely interrupted & $22(30.1)$ & $78(37.7)$ & $100(35.7)$ \\
\hline & $\begin{array}{l}\text { In part, I still do some activities at } \\
\text { school/university }\end{array}$ & $12(16.4)$ & $32(15.5)$ & $44(15.7)$ \\
\hline & $\begin{array}{l}\text { No, but all teaching and research } \\
\text { activities are now online }\end{array}$ & $39(53.4)$ & $94(45.4)$ & $133(47.5)$ \\
\hline & There were no interruptions & 0 & $3(1.4)$ & $3(1.1)$ \\
\hline \multirow{7}{*}{$\begin{array}{l}\text { How your professional } \\
\text { activities did are changed } \\
\text { during the epidemic? } \\
\text { ^ Excluding those without } \\
\text { professional activity }\end{array}$} & Completely interrupted & $141(29.6)$ & $156(24.3)$ & $297(26.5)$ \\
\hline & All activities started to be done at home & $134(28.2)$ & $218(33.9)$ & $352(31.5)$ \\
\hline & $\begin{array}{l}\text { Most activities started to be done at } \\
\text { home }\end{array}$ & $64(13.4)$ & $82(12.8)$ & $146(13.0)$ \\
\hline & $\begin{array}{l}\text { About half of the activities started to be } \\
\text { done at home }\end{array}$ & $26(5.5)$ & $39(6.1)$ & $65(5.8)$ \\
\hline & $\begin{array}{l}\text { Less than half of the activities started to } \\
\text { be done at home }\end{array}$ & $20(4.2)$ & $31(4.8)$ & $51(4.6)$ \\
\hline & Nothing has changed & $83(17.4)$ & $101(15.7)$ & $184(16.4)$ \\
\hline & $\begin{array}{l}\text { I was on vacation or medical leave during } \\
\text { the epidemic }\end{array}$ & $8(1.7)$ & $16(2.5)$ & $24(2.1)$ \\
\hline \multirow{5}{*}{$\begin{array}{l}\text { Indicate how much you agree/ } \\
\text { disagree with the following } \\
\text { statement: COVID-19 is a } \\
\text { major public health concern }\end{array}$} & I completely agree & $392(65.8)$ & $781(76.8)$ & $1,173(72.7)$ \\
\hline & I agree & $149(25.0)$ & $185(18.2)$ & $334(20.7)$ \\
\hline & I do not agree nor disagree & $34(5.7)$ & $39(3.8)$ & $73(4.5)$ \\
\hline & I disagree & $15(2.5)$ & $11(1.1)$ & $26(1.6)$ \\
\hline & I completely disagree & $6(1.0)$ & $1(0.1)$ & $7(0.4)$ \\
\hline \multirow{5}{*}{$\begin{array}{l}\text { Indicate how much you agree/ } \\
\text { disagree with the following } \\
\text { statement: Social distancing } \\
\text { was the right measure }\end{array}$} & I completely agree & $280(47.1)$ & $628(61.9)$ & $908(56.4)$ \\
\hline & I agree & $144(24.2)$ & $230(22.7)$ & $374(23.2)$ \\
\hline & I do not agree nor disagree & $80(13.4)$ & $88(8.7)$ & $168(10.4)$ \\
\hline & I disagree & $63(10.6)$ & $59(5.8)$ & $122(7.6)$ \\
\hline & I completely disagree & $28(4.7)$ & $10(1.0)$ & $38(2.4)$ \\
\hline
\end{tabular}

patients with COVID-19 ${ }^{10}$. In addition, physical inactivity is a well-known risk factor for many chronic non-communicable diseases ${ }^{42}$.
In the present study, $79.4 \%$ of the participants reported a large or very large impact of measures to contain the COVID-19 epidemic on 


\begin{tabular}{|c|c|c|c|c|c|c|c|c|c|}
\hline \multirow[t]{23}{*}{ 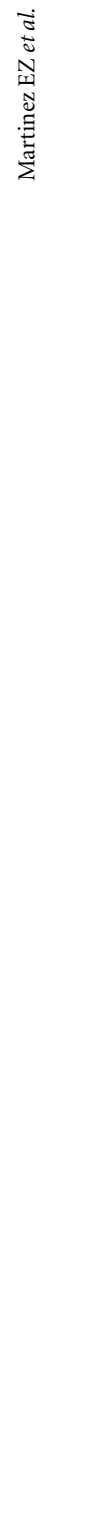 } & \multicolumn{9}{|c|}{$\begin{array}{l}\text { Table 3. Participants who practiced each activity until the beginning of the social distancing measures, the effects } \\
\text { on practice time during the period of social distancing due to COVID-19, and the number of people who started to } \\
\text { practice the activities during this period }(n=1,613) \text {. }\end{array}$} \\
\hline & \multirow{3}{*}{ Activity } & \multicolumn{3}{|c|}{$\begin{array}{l}\text { Persons who practiced each } \\
\text { activity until the beginning of } \\
\text { the period of social distancing } \\
\text { measures }\end{array}$} & \multicolumn{4}{|c|}{$\begin{array}{l}\text { Effects on practice time during the period } \\
\text { of social distancing }\end{array}$} & \multirow{2}{*}{$\begin{array}{c}\text { Started to } \\
\text { practice } \\
\text { the } \\
\text { activity } \\
\text { during } \\
\text { the period } \\
\text { of social } \\
\text { distancing }\end{array}$} \\
\hline & & Male & Female & Total & $\begin{array}{l}\text { Stopped } \\
\text { practicing }\end{array}$ & Reduced & $\begin{array}{l}\text { Not } \\
\text { changed }\end{array}$ & Increased & \\
\hline & & n (\%) & n (\%) & n (\%) & n (\%) & n (\%) & n (\%) & n (\%) & $\mathbf{n}$ \\
\hline & Strength training & $392(65.8)$ & $588(57.8)$ & $980(60.8)$ & $610(62.2)$ & $265(27.0)$ & $64(6.5)$ & $41(4.2)$ & 39 \\
\hline & Aerobic training & $270(45.3)$ & $446(43.9)$ & $716(44.4)$ & $308(43.0)$ & $261(36.5)$ & $84(11.7)$ & $63(8.8)$ & 52 \\
\hline & Outdoor activities & $218(36.6)$ & $329(32.4)$ & 547 (33.9) & $307(56.1)$ & $150(27.4)$ & $41(7.5)$ & $49(9.0)$ & 87 \\
\hline & Functional training & $148(24.8)$ & $267(26.3)$ & $415(25.7)$ & $170(41.0)$ & $161(38.8)$ & $43(10.4)$ & $41(9.9)$ & 164 \\
\hline & Stretching & $143(24.0)$ & $250(24.6)$ & $393(24.4)$ & $130(33.1)$ & $154(39.2)$ & $67(17.0)$ & $42(10.7)$ & 156 \\
\hline & Indoor or field sports & $122(20.5)$ & $59(5.8)$ & $181(11.2)$ & $171(94.5)$ & $7(3.9)$ & $1(0.6)$ & $2(1.1)$ & 10 \\
\hline & Pilates & $29(4.9)$ & $131(12.9)$ & $160(9.9)$ & $103(64.4)$ & $30(18.8)$ & $17(10.6)$ & $10(6.2)$ & 30 \\
\hline & Dance & $13(2.2)$ & $127(12.5)$ & $140(8.7)$ & $82(58.6)$ & $44(31.4)$ & $8(5.7)$ & $6(4.3)$ & 42 \\
\hline & Athletics & $81(13.6)$ & $56(5.5)$ & $137(8.5)$ & $57(41.6)$ & $54(39.4)$ & $17(12.4)$ & $9(6.6)$ & 13 \\
\hline & Water sports & $69(11.6)$ & $62(6.1)$ & $131(8.1)$ & $124(94.7)$ & $5(3.8)$ & $2(1.5)$ & - & 13 \\
\hline & Cross-fit & $42(7.0)$ & $79(7.8)$ & $121(7.5)$ & $74(61.2)$ & $29(24.0)$ & $10(8.3)$ & $8(6.6)$ & 14 \\
\hline & Yoga & $18(3.0)$ & $80(7.9)$ & $98(6.1)$ & $32(32.7)$ & $31(31.6)$ & $17(17.3)$ & $18(18.4)$ & 120 \\
\hline & Meditation & $16(2.7)$ & $68(6.7)$ & $84(5.2)$ & $10(11.9)$ & $24(28.6)$ & $27(32.1)$ & $23(27.4)$ & 129 \\
\hline & Martial arts, capoeira & $40(6.7)$ & $39(3.8)$ & 79 (4.9) & $62(78.5)$ & $11(13.9)$ & $2(2.5)$ & $4(5.1)$ & 13 \\
\hline & $\begin{array}{l}\text { High intensity interval } \\
\text { training (HIIT) }\end{array}$ & $29(4.9)$ & $44(4.3)$ & $73(4.5)$ & $27(37.0)$ & $19(26.0)$ & $13(17.8)$ & $14(19.2)$ & 51 \\
\hline & Hydrogymnastics & $2(0.3)$ & $23(2.3)$ & $25(1.5)$ & $23(92.0)$ & $2(8.0)$ & - & - & 12 \\
\hline & $\begin{array}{l}\text { Circus arts, slackline, } \\
\text { acrobatic gymnastics }\end{array}$ & $4(0.7)$ & $7(0.7)$ & $11(0.7)$ & $8(72.7)$ & $3(27.3)$ & - & - & 11 \\
\hline & $\begin{array}{l}\text { Tai-Chi-Chuan, Lian } \\
\text { Gong }\end{array}$ & $3(0.5)$ & $5(0.5)$ & $8(0.5)$ & $2(25.0)$ & $2(25.0)$ & $3(37.5)$ & $1(12.5)$ & 13 \\
\hline & Climbing & $2(0.3)$ & $3(0.3)$ & $5(0.3)$ & $5(100.0)$ & - & - & - & 10 \\
\hline
\end{tabular}

your physical activities, and many had to interrupt or decrease the frequency of their practices. Although the temporary closing fitness centers and gyms during the period of social distancing has contributed significantly to this scenario, this measure is essential for the mitigation of the disease, since the risk of infection for individuals participating in indoor physical activities increases during peak-times, when the ventilation required by those training is greater ${ }^{43}$. However, a number of authors claims that it is possible to maintain an active lifestyle during the period of social distancing, given that there is a wide range of physical exercises that can be performed at home ${ }^{18,44}$. The participants of the present study reported that during the COVID-19 epidem- ic they had online classes of physical activities, watched videos from the internet and live-stream videos, or received remote monitoring from a personal trainer. These resources are essential to motivate the continuity of an active lifestyle and should be encouraged. In addition, soon after the peak of COVID-19 infections is finally overcome and the measures of social distancing are reduced, it is important that outdoor activities are preferred over gyms, given these facilities may be considered a high-risk zone (see, as examples, the findings of Jang et al. ${ }^{45}$ and Furuse et $\mathrm{al}^{46}$ ). Thus, an important lesson from the COVID-19 pandemic is that outdoor locations like parks, sport courts, playgrounds and other public open spaces are essential to promote the health of the 
Table 4. Anxiety and depression according to characteristics of the participants $(n=1,613)$.

\begin{tabular}{|c|c|c|c|c|c|c|}
\hline & & & & anxiety & & depression \\
\hline & & Total & n (\%) & $\mathrm{PR}(95 \% \mathrm{CI})^{(\mathrm{a})}$ & n (\%) & $\operatorname{PR}(95 \% \mathrm{CI})^{(\mathrm{a})}$ \\
\hline \multirow[t]{2}{*}{ Gender } & Male & 596 & $472(79.2)$ & Ref. & $292(49.3)$ & Ref. \\
\hline & Female & 1017 & $855(84.6)$ & $1.06(1.01-1.11)^{\star}$ & $492(48.6)$ & $0.99(0.90-1.11)$ \\
\hline \multirow[t]{5}{*}{ Age (years) } & $18-25$ & 354 & $317(89.5)$ & Ref. & $169(47.7)$ & Ref. \\
\hline & $26-35$ & 527 & $450(85.9)$ & $0.96(0.91-1.01)$ & $253(48.3)$ & $1.01(0.88-1.17)$ \\
\hline & $36-45$ & 421 & $333(79.3)$ & $0.89(0.83-0.94)^{\star}$ & $214(51.2)$ & $1.07(0.93-1.24)$ \\
\hline & $46-60$ & 259 & $189(73.3)$ & $0.82(0.75-0.89)^{\star}$ & $129(50.0)$ & $1.05(0.89-1.23)$ \\
\hline & $>60$ & 52 & $38(74.5)$ & $0.83(0.70-0.99)^{\star}$ & $19(37.3)$ & $0.78(0.54-1.14)$ \\
\hline \multirow[t]{3}{*}{ Education level } & Fundamental II or less & 31 & $16(51.6)$ & Ref. & $13(41.9)$ & Ref. \\
\hline & Medium school & 384 & $338(88.0)$ & $1.55(1.09-2.19)^{\star}$ & $187(48.8)$ & $1.18(0.76-1.83)$ \\
\hline & Higher education & 1198 & $973(81.6)$ & $1.53(1.08-2.16)^{\star}$ & $584(49.0)$ & $1.18(0.77-1.79)$ \\
\hline \multirow{4}{*}{$\begin{array}{l}\text { Size of } \\
\text { household }\end{array}$} & Live alone & 439 & $361(82.8)$ & Ref. & $104(49.3)$ & Ref. \\
\hline & 2 people & 452 & $358(79.4)$ & $1.00(0.93-1.07)$ & $216(49.5)$ & $1.00(0.85-1.19)$ \\
\hline & 3 people & 510 & $436(85.7)$ & $0.96(0.88-1.03)$ & $215(47.9)$ & $0.97(0.82-1.15)$ \\
\hline & $>3$ people & 212 & $172(81.5)$ & $1.02(0.94-1.09)$ & $249(48.9)$ & $0.99(0.84-1.17)$ \\
\hline \multirow[t]{5}{*}{ Marital status } & Single & 764 & $668(87.5)$ & Ref. & $371(48.7)$ & Ref. \\
\hline & Married & 717 & $554(77.7)$ & $0.94(0.89-1.00)$ & $335(47.1)$ & $0.97(0.86-1.10)$ \\
\hline & Separated & 91 & $73(80.2)$ & $0.97(0.87-1.09)$ & $52(57.1)$ & $1.19(0.96-1.48)$ \\
\hline & Widowed & 19 & $13(72.2)$ & $0.97(0.73-1.28)$ & $12(63.2)$ & $1.33(0.91-1.95)$ \\
\hline & Other & 22 & $19(86.4)$ & $1.03(0.90-1.17)$ & $14(63.6)$ & $1.31(0.94-1.81)$ \\
\hline \multirow[t]{3}{*}{ Smoking status } & Never smoker & 1313 & $1081(82.6)$ & Ref. & $632(48.3)$ & Ref. \\
\hline & Smoker & 110 & $98(90.7)$ & $1.06(1.00-1.12)$ & $61(55.5)$ & $1.15(0.96-1.37)$ \\
\hline & Ex-smoker & 190 & $148(77.9)$ & $0.99(0.92-1.07)$ & $91(48.7)$ & $1.00(0.85-1.18)$ \\
\hline \multirow{3}{*}{$\begin{array}{l}\text { Self-perception } \\
\text { of health }\end{array}$} & Good & 1307 & $1057(81.2)$ & Ref. & $616(47.3)$ & Ref. \\
\hline & Regular & 300 & $264(88.3)$ & $1.09(1.04-1.14)^{\star}$ & $163(54.7)$ & $1.16(1.03-1.30)^{\star}$ \\
\hline & Poor & 6 & $6(100.0)$ & $1.23(1.20-1.26)^{\star}$ & $5(83.3)$ & $1.76(1.23-2.53)^{\star}$ \\
\hline \multirow{4}{*}{$\begin{array}{l}\text { Impact of social } \\
\text { distancing on } \\
\text { physical activities }\end{array}$} & Very large & 706 & $597(85.0)$ & Ref. & $364(51.9)$ & Ref. \\
\hline & Large & 575 & $473(82.4)$ & $0.97(0.92-1.02)$ & $275(47.8)$ & $0.92(0.82-1.03)$ \\
\hline & Low & 278 & $218(78.4)$ & $0.92(0.86-0.99)^{\star}$ & $117(42.4)$ & $0.82(0.70-0.95)^{\star}$ \\
\hline & Nothing has changed & 54 & $39(73.6)$ & $0.87(0.73-1.02)$ & $28(52.8)$ & $1.02(0.78-1.33)$ \\
\hline \multirow{4}{*}{$\begin{array}{l}\text { Impact of social } \\
\text { distancing on } \\
\text { daily life }\end{array}$} & Very large & 847 & $722(85.6)$ & Ref. & $441(52.2)$ & Ref. \\
\hline & Large & 614 & $497(81.2)$ & $0.95(0.90-0.99)$ & $278(45.5)$ & $0.87(0.78-0.97)^{\star}$ \\
\hline & Low & 139 & $100(71.9)$ & $0.84(0.75-0.94)^{\star}$ & $59(43.1)$ & $0.83(0.67-1.01)$ \\
\hline & Nothing has changed & 13 & $8(61.5)$ & $0.72(0.47-1.11)$ & $6(50.0)$ & $0.96(0.53-1.73)$ \\
\hline \multirow{4}{*}{$\begin{array}{l}\text { Information } \\
\text { search }\end{array}$} & All the time & 213 & $180(84.9)$ & Ref. & $98(46.2)$ & Ref. \\
\hline & Many times a day & 442 & $379(86.1)$ & $1.01(0.95-1.09)$ & $237(54.0)$ & $1.17(0.99-1.38)$ \\
\hline & A few times a day & 760 & $630(83.0)$ & $0.98(0.92-1.04)$ & $366(48.3)$ & $1.05(0.89-1.23)$ \\
\hline & Almost never & 197 & $137(70.3)$ & $0.83(0.74-0.92)^{\star}$ & $83(42.6)$ & $0.92(0.74-1.15)$ \\
\hline \multirow{5}{*}{$\begin{array}{l}\text { COVID-19 is a } \\
\text { major public } \\
\text { health concern }\end{array}$} & Completely agree & 1173 & $978(83.7)$ & Ref. & $537(46.0)$ & Ref. \\
\hline & Agree & 334 & $271(81.4)$ & $0.97(0.92-1.03)$ & $182(54.8)$ & $1.19(1.06-1.34)^{\star}$ \\
\hline & Do not agree nor disagree & 73 & $52(71.2)$ & $0.85(0.73-0.99)^{\star}$ & $41(56.2)$ & $1.22(0.99-1.51)$ \\
\hline & Disagree & 26 & $21(80.8)$ & $0.97(0.80-1.17)$ & $19(73.1)$ & $1.59(1.25-2.02)^{\star}$ \\
\hline & Completely disagree & 7 & $5(71.4)$ & $0.85(0.53-1.36)$ & $5(71.4)$ & $1.55(0.97-2.49)$ \\
\hline \multirow{5}{*}{$\begin{array}{l}\text { Social distancing } \\
\text { was the right } \\
\text { measure }\end{array}$} & Completely agree & 908 & 759 (83.9) & Ref. & $407(45.1)$ & Ref. \\
\hline & Agree & 374 & $297(80.1)$ & $0.95(0.90-1.01)$ & $180(48.4)$ & $1.07(0.94-1.22)$ \\
\hline & Do not agree nor disagree & 168 & $142(84.5)$ & $1.01(0.94-1.08)$ & $97(57.7)$ & $1.28(1.10-1.48)^{\star}$ \\
\hline & Disagree & 122 & $101(82.8)$ & $0.99(0.91-1.08)$ & $73(59.8)$ & $1.33(1.13-1.56)^{\star}$ \\
\hline & Completely disagree & 38 & $26(68.4)$ & $0.82(0.66-1.01)$ & $24(64.9)$ & $1.44(1.12-1.85)^{\star}$ \\
\hline
\end{tabular}


population and must be present in all cities. In this way, it is worth highlighting the importance of public policies for the development of actions aimed to reduce the levels of physical inactivity in the population and promotes to health, such as the Health Academy Program (founded by Brazilian Ministry of Health in 2011), which can help in times of pandemic ${ }^{47}$.

The results of the present study have potential limitations. First, self-selection bias is possible given that in the social networks like Facebook some individuals are more likely than others to complete an online survey ${ }^{48}$. This lim-

\section{Collaborations}

FM Silva and TL Silva participated in literature review and final review of the analysis and manuscript. G Dall'Agnol participated in literature review, data collection, data analysis and interpretation. MOZ Martinez, TZ Morigi and G Galdino participated in literature review, data collection and interpretation. EZ Martinez, ML Zucoloto, AG Joaquim and WR Silva participated in analysis and interpretation of results, writing of the manuscript, and final review of the analysis and manuscript. All authors participated in the drafting and approved the final version of the manuscript. itation may inhibit the ability to generalize the study findings to the general Brazilian population. Second, self-reported bias can also affect the results. Third, the cross-sectional design is a limitation because we could not establish a causal relationship among the variables. Despite these issues, this study brings evidence for the possible impacts of the periods of social distancing on the mental health of the individuals who practice physical activities and, therefore, new strategies for increasing and maintaining levels of physical activity in the population should be widely encouraged.

\section{Acknowledgments}

The authors wish to thank all the individuals who volunteered to participate in this study. 
4. Croda J, Oliveira WK, Frutuoso RL, Mandetta LH, Baia-da-Silva DC, Brito-Sousa JD, Monteiro WM, Lacerda MVG. COVID-19 in Brazil: advantages of a socialized unified health system and preparation to contain cases. Rev Soc Bras Med Trop. 2020; 53:e20200167.

5. Brasil. Lei 13.979, de 6 de fevereiro de 2020. Dispõe sobre as medidas para enfrentamento da emergência de saúde pública de importância internacional decorrente do coronavírus responsável pelo surto de 2019. Diário Oficial da União 2020; 7 fev.

6. Biscayart C, Angeleri P, Lloveras S, Chaves TSS, Schlagenhauf P, Rodríguez-Morales AJ. The next big threat to global health? 2019 novel coronavirus (2019$\mathrm{nCoV})$ : What advice can we give to travellers? - Interim recommendations January 2020, from the Latin-American society for Travel Medicine (SLAMVI). Travel Med Infect Dis. 2020; 33:101567.

7. Brazilian Ministry of Health. Painel Coronavirus. Available from: https://covid.saude.gov.br/. [cited 2020 May 15].

8. Mehrsafar AH, Gazerani P, Zadeh AM, Sánchez JCJ. Addressing potential impact of COVID-19 pandemic on physical and mental health of elite athletes. Brain Behav Immun 2020; S0889-1591(20):30781-30789.

9. Laddu DR, Lavie CJ, Phillips SA, Arena R. Physical activity for immunity protection: Inoculating populations with healthy living medicine in preparation for the next pandemic. Prog Cardiovasc Dis 2020:S00330620(20)30078-30075.

10. Souza Filho BAB, Tritany EF. COVID-19: the importance of new technologies for physical activity as a public health strategy. Cad Saude Publica 2020; 36(5):00054420.

11. Halabchi F, Ahmadinejad Z, Selk-Ghaffari M. COVID-19 Epidemic: Exercise or not to exercise; that is the question! Asian J Sports Med 2020; 11(1); e102630.

12. Ahmadinejad Z, Alijani N, Mansori S, Ziaee V. Common sports-related infections: a review on clinical pictures, management and time to return to sports. Asian J Sports Med 2014; 5(1):1-9.

13. Chen P, Mao L, Nassis GP, Harmer P, Ainsworth BE, Li F. Coronavirus disease (COVID-19):The need to maintain regular physical activity while taking precautions. J Sport Health Sci 2020; 9(2):103-104.

14. American College of Sports. (ACSM). Staying active during the coronavirus pandemic. [Internet]. [cited 2020 Mar 16]. Available from: https://www. exerciseismedicine.org/assets/page_documents/EIM_ Rx\%20for\%20Health_\%20Staying\%20Active\%20 During\%20Coronavirus\%

15. Hall G, Laddu DR, Phillips SA, Lavie CJ, Arena R. A tale of two pandemics: How will COVID-19 and global trends in physical inactivity and sedentary behavior affect one another? Prog Cardiovasc Dis 2020; S00330620(20)30077-30073.

16. Demirci, N. Fight Coronavirus Disease (COVID-19): More Active People for a Healthier World: Physical Activity Recommendations. Int J Disabil Sports Health Sci. 2020; 3(1):1-4.

17. Hammami A, Harrabi B, Mohr M, Krustrup P. Physical activity and coronavirus disease 2019 (COVID-19):specific recommendations for homebased physical training. Manag Sport Leis 2020; 1-6.

18. Jiménez-Pavón D, Carbonell-Baeza A, Lavie CJ. Physical exercise as therapy to fight against the mental and physical consequences of COVID-19 quarantine: Special focus in older people. Prog Cardiovasc Dis 2020; 63(3):386-388.

19. Oliveira Neto L, Elsangedy HM, Oliveira Tavares VD, Teixeira CVLS, Behm DG, Silva-Grigoletto ME. \#TrainingInHome - Home-based training during COVID-19 (SARS-COV2) pandemic: physical exercise and behavior-based approach. Rev Bras Fisiol Exerc 2020; 19(2):4-14.

20. Peçanha T, Goessler KF, Roschel H, Gualano B. Social isolation during the COVID-19 pandemic can increase physical inactivity and the global burden of cardiovascular disease. Am J Physiol Heart Circ Physiol 2020; 318(6):H1441-H1446.

21. Filgueiras A, Stults-Kolehmainen M. The relationship between behavioural and psychosocial factors among Brazilians in quarantine due to COVID-19. [cited 2020 Mar 16]. Available at: http://dx.doi.org/10.2139/ ssrn.3566245

22. Ferreira MJ, Irigoyen MC, Consolim-Colombo F, Saraiva JFK, De Angelis K. Physically active lifestyle as an approach to confronting COVID-19. Arq Bras Cardiol 2020; 114(4):601-602.

23. Eysenbach, G. Improving the quality of Web surveys: the Checklist for Reporting Results of Internet E-Surveys (CHERRIES). J Med Internet Res 2004; 6(3):e34.

24. Harris PA, Taylor R, Thielke R, Payne J, Gonzalez N, Conde JG. Research electronic data capture (REDCap) - a metadata-driven methodology and workflow process for providing translational research informatics support. J Biom Inform 2009; 42(2):377-381.

25. Stewart AL, Greenfield S, Hays RD, Wells K, Rogers WH, Berry SD, McGlynn EA, Ware Junior JE. Functional status and well-being of patients with chronic conditions. Results from the Medical Outcomes Study. JAMA 1989; 262(7):907-913.

26. Jylhä M. What is self-rated health and why does it predict mortality? Towards a unified conceptual model. Soc Sci Med 2009; 69(3):307-316.

27. Vyas R, Dikshit N. Effect of meditation on respiratory system, cardiovascular system and lipid profile. Indian J Physiol Pharmacol 2002; 46(4):487-491.

28. Snaith RP. The hospital anxiety and depression scale. Health Qual Life Outcomes 2003; 1(1):29.

29. Zigmond AS, Snaith RP. The hospital anxiety and depression scale. Br Med J (Clin Res Ed) 1986; 292(6516):344. 
30. Botega, NJ. Bio MR, Zomignani MA, Garcia Júnior C, Pereira WAB. Mood disorders among medical in-patients: a validation study of the hospital anxiety and depression scale (HAD). Rev Saude Publica 1995; 29(5):359-363.

31. Bjelland I, Dahl AA, Haug TT, Neckelmann D. The validity of the Hospital Anxiety and Depression Scale: an updated literature review. J Psychosom Res 2002; 52(2):69-77.

32. Bernik MA, Lotufo-Neto F. Instrumentos de avaliação de ansiedade. In: Gorenstein C, Wang YP, Hungerbühler I, organizadores. Instrumentos de avaliação em saúde mental. Porto Alegre: Artmed; 2016. p.149-183.

33. Donoghoe MW, Marschner IC. logbin: An R package for relative risk regression using the log-binomial model. J Stat Softw 2018; 86(1):1-22.

34. Fluetsch N, Levy C, Tallon L. The relationship of physical activity to mental health: A 2015 behavioral risk factor surveillance system data analysis. J Affect Disord 2019; 253:96-101.

35. McDowell CP, Gordon BR, Andrews KL, MacDonncha C, Herring MP. Associations of physical activity with anxiety symptoms and status: results from The Irish longitudinal study on ageing. Epidemiol Psychiatr Sci 2019; 28(4):436-445.

36. Kong X, Zheng K, Tang M, Kong F, Zhou J, Diao L, Wu S, Jiao P, Su T, Dong Y. Prevalence and factors associated with depression and anxiety of hospitalized patients with COVID-19. medRxiv 2020; 2020.03.24.20043075.

37. Garcia-Priego BA, Triana-Romero A, Pinto-Galvez SM, Duran-Ramos C, Salas-Nolasco O, Reyes MM, Medina AR, Troche JMR. Anxiety, depression, attitudes, and internet addiction during the initial phase of the 2019 coronavirus disease (COVID-19) epidemic: A cross-sectional study in Mexico. medRxiv 2020; 2020.05.10.20095844.

38. Wong WS, Fielding R. Prevalence of chronic fatigue among Chinese adults in Hong Kong: a population-based study. J Affect Disord 2010; 127(1-3):248256.

39. Crawford JR, Garthwaite PH, Lawrie CJ, Henry JD, MacDonald MA, Sutherland J, Sinha P. A convenient method of obtaining percentile norms and accompanying interval estimates for self-report mood scales (DASS, DASS-21, HADS, PANAS, and sAD). Br J Clin Psychol 2009; 48(Pt 2):163-180.

40. Yun YH, Kim SH, Lee KM, Park SM, Kim YM. Age, sex, and comorbidities were considered in comparing reference data for health-related quality of life in the general and cancer populations. J Clin Epidemiol 2007; 60(11):1164-1175.
41. Hinz A, Finck C, Gómez Y, Daig I, Glaesmer H, Singer $\mathrm{S}$. Anxiety and depression in the general population in Colombia: reference values of the Hospital Anxiety and Depression Scale (HADS). Soc Psychiatry Psychiatr Epidemiol 2014; 49(1):41-49.

42. Booth FW, Roberts CK, Laye MJ. Lack of exercise is a major cause of chronic diseases. Compr Physiol 2012; 2(2):1143-1211.

43. Andrade A, Dominski FH, Pereira ML, Liz CM, Buonanno G. Infection risk in gyms during physical exercise. Environ Sci Pollut Res 2018; 25(20):1967519686.

44. Lippi G, Henry BM, Sanchis-Gomar F. Physical inactivity and cardiovascular disease at the time of coronavirus disease 2019 (COVID-19). Eur J Prev Cardiol 2020; 2047487320916823.

45. Jang S, Han SH, Rhee JY. Cluster of coronavirus disease associated with fitness dance classes, South Korea. Emerg Infect Dis 2020; 26(8).

46. Furuse Y, Sando E, Tsuchiya N, Miyahara R, Yasuda I, Ko YK, Saito M, Morimoto K, Imamura T, Shobugawa Y, Nagata S, Jindai K, Imamura T, Sunagawa T, Suzuki M, Nishiura H, Oshitani H. Clusters of Coronavirus Disease in Communities, Japan, January-April 2020. Emerg Infect Dis 2020; 26(9).

47. Sá GBAR, Dornelles GC, Cruz KG, Amorim RCA, Andrade SSCA, Oliveira TP, Silva MMA, Malta DC, Souza MFM. The Health Academy Program as a strategy to promote health and healthy lifestyles: the national implementation scenario. Cien Saude Colet 2016; 21(6):1849-1860.

48. Wright KB. Researching Internet-based populations: Advantages and disadvantages of online survey research, online questionnaire authoring software packages, and web survey services. J Comp Mediated Comm 2005; 10(3):1034.

Article submitted 30/05/2020

Approved 23/07/2020

Final version submitted 25/07/2020 